\title{
Comparative Study of Biogas Production from Anaerobic Co-digestion of Donkey Dung and Swine Dung
}

\author{
Ogala Harrison ${ }^{1, *}$, Ige Ayodeji Rapheal ${ }^{2}$, Elinge Cosmos Moki \\ ${ }^{1}$ Department of Chemical Sciences, Admiralty University of Nigeria, Asaba, Nigeria \\ ${ }^{2}$ Department of Pure and Applied Chemistry, Kebbi State University of Science and Technology, Aliero, Nigeria \\ Email address: \\ ogalaharrison@gmail.com (O. Harrison) \\ ${ }^{*}$ Corresponding author
}

\section{To cite this article:}

Ogala Harrison, Ige Ayodeji Rapheal, Elinge Cosmos Moki. Comparative Study of Biogas Production from Anaerobic Co-digestion of Donkey Dung and Swine Dung. International Journal of Biochemistry, Biophysics \& Molecular Biology. Vol. 5, No. 2, 2020 , pp. $34-38$. doi: $10.11648 /$ j.ijbbmb.20200502.13

Received: June 16, 2020; Accepted: June 30, 2020; Published: October 30, 2020

\begin{abstract}
Production of sufficient sustainable sources of energy, mitigation of green house gas emissions amongst others are the aspiring goals that have led in developing technologies to produce more energy from renewable sources. This study investigated the potentials of an alternative fuel sources for biogas production, it was carried out using donkey dung and swine dung as substrates, further co-digestion of both donkey dung and swine dung was done to differentiate between independent and co-digestion of substrates. Digesters were used to digest swine dung and donkey dung respectively as single substrates as well as to co-digest swine dung and donkey dung. The operating conditions here are $\mathrm{pH}$ value 7.2 , Temperature $32^{\circ} \mathrm{C}$ and retention time of 68 days. Effect of seeding with bacteria increases the rate of production and mixing is an essential part that also aids the production of biogas. This work presents the design and construction of biogas digester to treat $500 \mathrm{~g}$ of swine dung and donkey dung. The digester is capable of producing $0.007 \mathrm{~m}$ at average working temperature of $32^{\circ} \mathrm{C}$. Digester $\mathrm{D}$ produces higher volume of biogas. Therefore, from the values of the physic-chemical properties with the sufficient carbon obtained, it will increase the sufficient effective biogas production as an alternative source of energy.
\end{abstract}

Keywords: Biogas, Digester, Production, Dung, Temperature

\section{Introduction}

As demand for energy by man is excessively increasing and there has been a relentless search for the different forms of energy that will meet up with this energy demand [1]. Biowaste refers to the agricultural waste, forestry waste, livestock manures, the biodegradation part of municipal waste including food and garden waste, treated sewage, organic industrial waste such as paper, textile and compost, which are detrimental to the environment if not manage properly.

Bio-waste is a biomass and thus renewable energy source not only because the energy it produces is obtained from the sun, but because bio-waste can be re-grown over a relatively short period of time through the process of photosynthesis. Chlorophyll in plant captures the sun energy by converting carbon dioxide in the air and water in the ground into carbohydrate, hydrogen and oxygen. When these carbohydrates are burned, they release carbon dioxide and water and thus, energy captured from the sun is release. In this way bio-waste is produced sustainably, meeting current needs without diminishing resources of land's capacity to regrow bio-waste and capture carbon, the battery will last indefinitely and provide source of low-carbon energy [2].

Bio-waste can be converted to other usable forms of energy like methane gas or transportation of fuels like biodiesel, bio-ethanol, bio-oil, and briquette. Decomposed garbage, agriculture and human waste release methane gas and are called "landfilled gas". Crops like sugar cane and corn can be fermented to automobile fuels, such as bioethanol. Bio-waste can be degraded aerobically to produce biogas and other gases. Biogas is a mixture of methane $\left(\mathrm{CH}_{2}\right), 50$ to $70 \%$ carbon dioxide $\left(\mathrm{CO}_{2}\right), 30$ to $40 \%$ Hydrogen $\left(\mathrm{H}_{2}\right), 5$ to $10 \%$ nitrogen $\left(\mathrm{N}_{2}\right)$ and 1 to $2 \%$ hydrogen sulphide $\left(\mathrm{H}_{2} \mathrm{~S}\right)$, water vapor $(0.3 \%)$. Methane is the major constituent 
of biogas and it is a worthily renewable source of energy [3, $4]$, it is a colorless and odorless gas that burns with $60 \%$ efficiency in a conventional biogas store [1].

\section{Materials and Methods}

The materials used were donkey dung and swine dung. The samples were collected in Aliero, Aliero Local Government, Kebbi State, and Northern western Nigeria. The dungs were sun dried for 2-3 days and grounded using mortar and pestle. The dried pulverized samples were stored in tight containers until further analysis.

\subsection{Substrates Analysis}

Proximate analysis of these substrates was carried out to determine their Total solids (TS), voluble solid (VS), carbon content, nitrogen content, ash content, moisture content, nitrogen/carbon ratio $(\mathrm{C}: \mathrm{N})$ ratio and $\mathrm{pH}$ before and after digestion process.

\subsubsection{Total Solids (TS)}

These are the sums of suspended solids and dissolved solids. The total solids are composed of two components, Volatile Solid (VS) and Fixed Solid. This was determined using [6] procedure.

Equation (1) was used to calculate the percentage total solids.

$$
\mathrm{TS}(\%)=\frac{(\mathrm{W} 1-\mathrm{W} 2) \times 100}{(\mathrm{~W} 3-\mathrm{W} 3)}
$$

where,

$\% \mathrm{TS}=$ Percentage total solid

$\mathrm{W} 1=$ Weight of dried crucible + dried residue

W2 $=$ Weight of crucible

W3 =Weight of wet sample (substrate) + crucible

\subsubsection{Volatile Solids (VS)}

The volatile solids are organic portion of TS that biodegradable anaerobically. This parameter was determined using the procedure of Sunneer at et al., [5].

Equation (2) was used to calculate the percentage volatile solids.

$$
\mathrm{VS}(\%)=\frac{(\mathrm{W} 1-\mathrm{W} 3) \times 100}{(\mathrm{~W} 1-\mathrm{W} 2)}
$$

Where, $\mathrm{W} 1=$ weight of dish + dried sample at $75^{\circ} \mathrm{C}(\mathrm{g})$, $\mathrm{W} 2=$ weight of dish $(\mathrm{g})$,

$\mathrm{W} 3=$ weight of dish + sample after ignition at $550^{\circ} \mathrm{C}(\mathrm{g})$ and $\mathrm{D}=$ weight of dish + wet sample $(\mathrm{g})$.

\subsubsection{Determination of Moisture Content}

The determination was carried out for both substrates and digestates. For all samples, clean and dry Petri dish was weighed $\left(\mathrm{W}_{0}\right) .2 .0 \mathrm{~g}$ of each sample was taken and placed in the Petri dish such that the total weight of the loaded sample dish would be $\left(\mathrm{W}_{\mathrm{b}}\right)$. The loaded dish was then placed in Gallen Kamp Oven and adjusted to a constant temperature of $105^{\circ} \mathrm{c}$ for 24 hours. The dish will then be removed from the oven and placed in the desiccators to cool. When it cooled, the dish with its content was weighed, to obtained $\left(\mathrm{W}_{\mathrm{a}}\right)$. The moisture content was evaluated using Masséetal., [7] procedure.

$$
\% \text { moisture }=\frac{\mathrm{W}_{a}-\mathrm{W}_{b}}{W_{s}}
$$

Where $\mathrm{W}_{\mathrm{b}}=$ Mass of sample and dish before drying $\mathrm{W}_{\mathrm{a}}=$ Mass of sample and dish after drying

$\mathrm{W}_{\mathrm{s}}=$ Mass of the sample taken

\subsubsection{Determination of Ash Content}

This was carried out for both substrates and digesters. Porcelain crucibles was washed and dried for each sample and weighed as $\left(\mathrm{W}_{1}\right)$. A $2.0 \mathrm{~g}$ of respective sample was weighed into crucible as $\left(\mathrm{W}_{2}\right)$ and placed in lenthon furnace and was heated at $600^{\circ} \mathrm{C}$ for 3 hours.

The furnace was switched off and then allows the crucible to cool. Thereafter, the sample was removed from the furnace and placed in desiccators to further cool down at room temperature. The percentage ash content was determined using the procedure of Murtoetal., [8].

Equation (4) was used to calculate the percentage ash content.

$$
\% \mathrm{AC}=\frac{\mathrm{W}_{2}-\mathrm{W}_{3 X} 100}{W_{2}}
$$

Where,

$\mathrm{AC}=$ Ash Content

$\mathrm{W}_{3}=$ Weight of crucible and sample after heating

$\mathrm{W}_{2}=$ Weight of crucible and sample before heating

\subsubsection{Determination of Total Carbon}

Total carbon was determined according to Walkely Black methods as described by Karki et al., [9].

\subsubsection{Determination of Total Nitrogen}

Two grams of each powdered sample in an Ash fewer filter was dropped into $500 \mathrm{~cm}^{3}$ kjeldahl flask. Three grams of digesting catalyst (selenium) and $10 \mathrm{ml}$ conc. $\mathrm{H}_{2} \mathrm{SO}_{4}$ was also dropped into the kjedahl flask. The sample will digest until a clear green colour is obtained. The digestion was allowed to cool and was diluted into $100 \mathrm{ml}$ with distilled water. $20 \mathrm{ml}$ of diluted digest was measured into $500 \mathrm{ml}$ kjeldahl flask containing ant-bumping chips and $40 \mathrm{ml}$ of $40 \% \mathrm{NaOH}$ was slowly added by the side of the flask. A $250 \mathrm{ml}$ conical flask containing a mixture of $50 \mathrm{ml} 20 \%$ boric acid and 4 drops of mixed indicators was used to trap the ammonia being liberated. The conical flask and the kjeldahl flask was then placed on the kjeldahl distillation apparatus with the tubes inserted into the conical flask and kjedahl flask. The flask was heated to distil out the $\mathrm{NH}_{3}$ evolved. The distillate was collected into the boric acid solution, when the boric acid turned green, it was allowed for 10 minutes to complete distillation of the ammonia present in the digest. The distillate was then titrated with $0.1 \mathrm{M} \mathrm{HCl}$.

Calculation: \%Nitrogen $\left(\mathrm{N}_{2}\right)=14 \times M x V t x T V x 100 /$ Weight of Sample (mg) xVa 
Where,

$\mathrm{M}=$ Actual Molarity of Acid

$\mathrm{TV}=$ Titre Volume of $\mathrm{HCl}$ used

$\mathrm{Vt}=$ Total Volume of Diluted Digester

$\mathrm{Va}=$ Aliquot Volume Distilled [10]

\subsubsection{Determination of Carbon to Nitrogen (C: N) Ratio}

This was determined using the [10] procedure by dividing the value of total carbon by the value of total nitrogen.

\subsection{Fermentation of the Slurry}

Preparation of fermentation slurry was done by addition and vigorous mixing of total solid with an equivalent amount of water needed for maximum yield. The water content for each sample was determined using the recommendation for better biogas production as reported by Sadaa, et al, [11], that is, a total solid (TS) of $8 \%$ in the fermentation slurry. This was the basis for the determination of the amount of water to be added for any given mass of total solid. Hence, the proportion of total solid in the slurries was the same in all the digesters.

The $\mathrm{pH}$ of the slurry was measured before and after digestion.

Table 1. The Procedures taken during Mounting of the Digesters are as follows;

\begin{tabular}{lll}
\hline Digesters & Content (gram) & $\begin{array}{l}\text { Volume of water } \\
\text { (litres) }\end{array}$ \\
\hline Digester A & A $(500 \mathrm{~g})$ & $3000 \mathrm{mls}$ \\
Digester B & B (500g) & $4000 \mathrm{mls}$ \\
Digester C & C (300g and 200g) & $3200 \mathrm{mls}$ \\
Digester D & D (200g and 300g) & $3600 \mathrm{mls}$ \\
\hline
\end{tabular}

\subsection{Experimental Design}

A hole was bored on the lid of the can by a machine (chissle). One end of the hose pipe (which served as a delivery tube for the gas) was inserted into the hole bored on the lid, epoxy steel gum was then applied around the hole to ensure that no air seep into or out of the digester.

The animal dung (slurry) was then feed into the digester (Can) and then was covered with the lid which has already been connected to the hose pipe. Gum was applied around the circumference of the can lid to ensure an airtight condition which is necessary for anaerobic digestion.

The plastic bowls was filled with water and measuring cylinder containing water was then inserted into the plastic bowls filled with water avoiding bubbles of air. The retort stand was used to hold the measuring cylinder vertically in the bowls. The other end of the hose pipe was introduced into the water basin and passed through the measuring cylinder for the collection of gas produced. The volume of the water displaced is proportional to the volume of biogas generated.

The mode of loading was a discontinued feeding (batch feeding). This simply means loading the digester was at once and maintaining a closed environment throughout the retention period. Four different digesters was prepared for loading. These digesters were labelled as follows:
Digester A -Swine Dung only

Digester B - Donkey Dung only

Digester C - Swine (300g) and Donkey Dung (200g)

Digester D - Swine (200g) and Donkey Dung (300g)

\section{Results}

Table 2. Proximate Analysis of the Substrate before Anaerobic Co-digestion.

\begin{tabular}{lll}
\hline PARAMETERS & SUBSTRATE A & SUBSTRATE B \\
\hline Total Solid & 97.0 & 93.5 \\
Volatile Solid & 44.9 & 45.0 \\
Total Nitogen & 5.5 & 35.0 \\
Total Carbon & 6.5 & 9.8 \\
Ash Content & 28.0 & 43.5 \\
Moisture Content & 18.5 & 18.1 \\
\hline
\end{tabular}

Table 3. Result of Proximate analysis of the Digestate after Anaerobic Digestion.

\begin{tabular}{lllll}
\hline Parameters & Digester A & Digester B & Digester C & Digester D \\
\hline Total solids & 98.5 & 96.5 & 98.0 & 96.5 \\
Volatile solids & 61.0 & 53.5 & 72.0 & 40.0 \\
Total carbon & 8.0 & 5.0 & 2.03 & 2.61 \\
Total nitrogen & 6.5 & 9.8 & 0.91 & 1.37 \\
Ash content & 26.5 & 21.5 & 6.5 & 7.5 \\
Moisture & 3.0 & 6.5 & 4.5 & 3.5 \\
content & & & & \\
\hline
\end{tabular}

Table 4. Result of PH of the slurries and digestate before and after anaerobic digestion.

\begin{tabular}{lllll}
\hline PH & Digester A & Digester B & Digester C & Digester D \\
\hline Before & 8.00 & 8.23 & 8.12 & 8.20 \\
After & 9.45 & 8.93 & 9.02 & 8.92 \\
\hline
\end{tabular}

Table 5. Result of cumulative weekly biogas production with temperature for the four digesters.

\begin{tabular}{llllll}
\hline $\begin{array}{l}\text { Time } \\
(\text { weeks) }\end{array}$ & $\begin{array}{l}\text { Temperature } \\
\left({ }^{\circ} \mathbf{C}\right)\end{array}$ & $\begin{array}{l}\text { Digester } \\
\mathbf{A}(\mathbf{m l})\end{array}$ & $\begin{array}{l}\text { Digester } \\
\mathbf{B}(\mathbf{m l})\end{array}$ & $\begin{array}{l}\text { Digester } \\
\mathbf{C}(\mathbf{m l})\end{array}$ & $\begin{array}{l}\text { Digester } \\
\mathbf{D}(\mathbf{m l})\end{array}$ \\
\hline 1 & 34 & 361 & 147 & 1221 & 372 \\
2 & 34 & 2880 & 2314 & 4624 & 4650 \\
3 & 34 & 4851 & 5108 & 5464 & 5908 \\
4 & 36 & 3467 & 3527 & 4470 & 4943 \\
5 & 34 & 4022 & 3644 & 3175 & 5672 \\
\hline
\end{tabular}

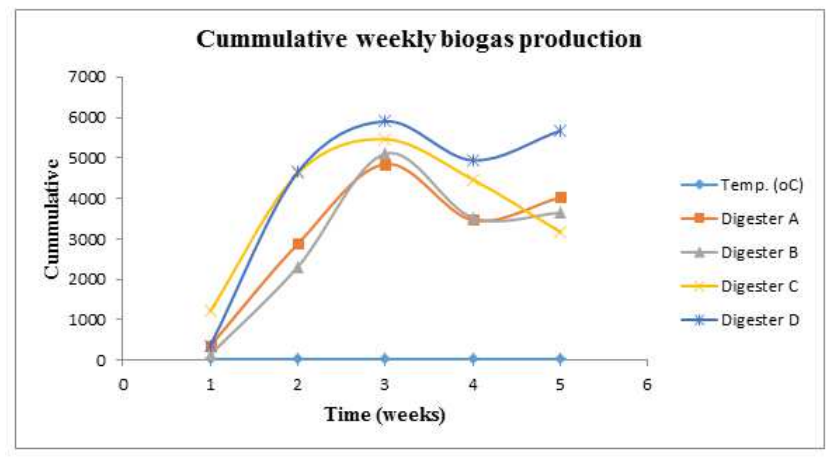

Figure 1. Graph Cummulative Weekly Biogas Production.

\section{Discussion}

The results of total solid (TS) for the sample A and B before digestion were $97.0 \%$ and $93.5 \%$ respectively. After 
the anaerobic digestion, there was an increase in the values of total solid for the two substrates. The values are $98.5 \%$ and 96.5\% respectively for digester A and B. Digester C and D have the following values $98.0 \%$ and $96.5 \%$ respectively.

The sample B has the highest value compared to the other sample B. After the anaerobic digestion, there was an increase in the result of the volatile solid for the two digesters. The values are $61.0 \%$ and $53.5 \%$ for digester $\mathrm{A}$ and $\mathrm{B}$ respectively. The values for digester $\mathrm{C}$ and $\mathrm{D}$ are $72.0 \%$ and $40.0 \%$ respectively. The increase in the values is as a result of the high volatile solid that has been converted to biogas.

There was a decrease in the value of total nitrogen in the samples as a result of the bacteria that have utilized the nitrogen for their metamorphic growth process. This was in line with earlier submissions by various researches.

After the anaerobic digestion, the values of Ash content were $26.5 \%$ and $21.5 \%$ for digester $\mathrm{A}$ and $\mathrm{B}$ respectively. Digester $C$ and $D$ have the following values $6.5 \%$ and $7.5 \%$ respectively. There was a decrease in the value of Ash content of the substrates after the anaerobic digestion. Similar report was presented by Yavini et al., [12].

Substrate A has the higher moisture content before digestion. After the anaerobic digestion, the values of moisture content were 3.0 and 6.5 for digester $\mathrm{A}$ and $\mathrm{B}$ respectively Digester $C$ and $D$ have the following values 4.5 and 3.5 respectively. the moisture content values are compare well with $74.8 \%$ digestate sample as reported by Dabrowska et al., [13].

$\mathrm{pH}$ is an important factor that affects anaerobic digestion as reportedbyNeczajetal., [14] the values of the $\mathrm{pH}$ before the anaerobic digestion of the four (4) slurries are 8.00, 8.23, 8.12 and 8.62 for digester $\mathrm{A}, \mathrm{B}, \mathrm{C}$ and $\mathrm{D}$ respectively. It has been reported that anaerobic bacteria required a neutral environment and thus a $\mathrm{pH}$ ranging from 6.4-7.2 is needed for optimum biogas production as described by Aremu \& Agarry [15]. There was an increase in the $\mathrm{pH}$ of the digestate after the anaerobic digestion. The values obtained are compare well with $7.2 \mathrm{pH}$ of solid fuel used for biogas production as reported by Soliu, et al., [16].

After the anaerobic digestion, the values of total carbon were 8.0 and 5.0 for substrate A and B respectively. Digester $\mathrm{C}$ and $\mathrm{D}$ have the following values 2.03 and 2.61 respectively. There was a decrease in the values; this might be as a result of biogas formation.

The temperature range throughout the retention periods is within $34-36^{\circ} \mathrm{C}$ which is optimum for biogas production under mesophilic condition. this also validate the temperature range cited by Babatola, [17], At low temperature, microorganism become inactive and rate of gas production drops but resumes when the temperature is favorable.

In Digester A (swine dung) only, biogas production started on the 4th day of the retention period because it takes more time for swine dung to decompose after which gas is being produced by producing $90 \mathrm{ml}$ of biogas. This is expected because biogas production rate in batch condition is directly equal to specific growth of methanogenic bacteria (Babatola
2008). The Digester A may be attributed to its high value of $\mathrm{pH}$ value which was slightly above the optimum $\mathrm{pH}$ range cited by Ubalua (2008) (6.9-7.3 \& 6.4-7.6 respectively).

In Digester B (donkey dung), biogas production began on the 5 th day of the retention period by producing $60 \mathrm{ml}$ of biogas. A peak production of $1,160 \mathrm{ml}$ was recorded on the 22nd day of the retention period and thereafter reduced each day till the 50th day of retention period. After this, there was a slow production till the end of the retention period.

In Digester C (swine and donkey dung 300g-200g). The biogas production began on the 5th day of the retention period with $100 \mathrm{ml}$ of biogas produced. This was similar to the work of Ubalua (2008) stated that the production of biogas from mixture of gasses created from methanogenic bacteria which break down the organic matter in an anaerobic condition. The production increased daily till a peak of average production of $4470 \mathrm{ml}$ on the 5 th week of production, thereafter it was observed that as the temperature increases, there was a good production. Digester $\mathrm{C}$ has a great potential in biogas production revealed from its value of volatile matter, carbon content and total solid. Swine dung was classified among the best substrates for bio-digestion.

In Digester D (donkey and swine dung 300g and 200g). The production began on the 3rd day of the retention period by producing $40 \mathrm{mls}$ of biogas. The production subsequently increases and decreases day by day. The highest production was recorded on the $3 \mathrm{rd}$ and 4 th week with the value of $1300 \mathrm{ml}$ and $1130 \mathrm{ml}$. Digester D produces higher volume of biogas compared to digester B. This was as the result of improved nutrient provided by donkey dung, there was a reduction in the startup time.

\section{Conclusion}

Biogas production from anaerobic co-digestion of swine and donkey dung was established in this research work to be feasible of mesophilic temperature range and this gives positive attribute towards a search for sustainable renewable energy source (SRES) to substitute the fast depleting fossil fuels. Digester D produces higher volume of biogas. This was as the result of improved nutrient provided by donkey dung and has the best neutral $\mathrm{pH}$, there was a reduction in the startup time.

\section{References}

[1] Iyagba, E. I., Mangibo, I. A. and Mohammad, Y. S. (2009) The study of cow dung as co-substrate with rice husk in biogas production. Scientific Research Essays, 4 (9), 861-868.

[2] Muzenda E. (2014). Bio-methane Generation from Organic Waste: A Review. Proceedings of the World Congress on Engineering and Computer Science, VolII, WCECS 2014, 2224 October, 2014, San Francisco, US.

[3] Suneerat P, Sommas K and Tharapong V. (2009). Economic assessment of biogas to Electricity generation system with $\mathrm{H} 2 \mathrm{~S}$ removal by activated carbon in small pig farm Scientific Res. And Essay, 4 (9): 861-886. 
[4] Mussoline, W., Esposito, G., Lens, P., Garuti, G., Giordano, A (2012). Design considerations for a farm-scale biogas plant based onpilot-scale anaerobic digesters loaded with rice straw and piggery wastewater, Biomass. Bioenerg., 46, 469-478.

[5] Ebunilo, P. O., Orhorhoro, E. K., \& Adegbayi, O. A (2016). Investigation of the purification of biogas from domestic wastes using local materials in Nigeria, International Journal of Scientific \& Engineering Research, Volume 7, Issue 2, 505515.

[6] Ejiroghene Kelly Orhorhoro, Patrick Okechukwu Ebunilo, Godwin Ejuvwedia Sadjere. Experimental Determination of Effect of Total Solid (TS) and Volatile Solid (VS) on Biogas Yield. American Journal of Modern Energy. Vol. 3, No. 6, 2017, pp. 131-135. doi: 10.11648/j.ajme.20170306.13.

[7] Massé D. I., Talbot G. and Gibert Y. (2011). In farm biogas production: A method to reduce GHG emissions and develop more sustainable live stock operations, Animal Feed Sci. Techn., 166: 436-445.

[8] Murto M., Bjornsson L., and Mattiasson B. (2004). Impact of food industrial waste anaerobicco digestion of sewage sludge and pig manure. Journal of Environmental Management, 70 (2), 101-107.

[9] Karki AB, Shresta J. N. and Bajgain S. (2005). Biogas, As Renewable Source of Energy in Nepal, The ory and Development, BSP-Nepal Publishing, Kathmandu, 1-12.

[10] Batstone, D, J, J, Keller, I, Angelidaki, S, V. Kalyuzhnyi, S. G, Pavlostathis, A. Rozzi, W, T. M. Sandersand V. A. Vanilin, (2002) Anaerobic Digestion Model No. 1 (ADMI). IWA Task Group for Mathematical Modelling of Anaerobic Digestion Processes, IWA Publishing, London, UK.

[11] Sadaa, B. H., Amarteyb, Y. D., Bako, S. (2013). An investigation into the use of groundnut shell as fine aggregate replacement. Nigerian Journal of Technology (NIJOTECH) Vol. 32 (1), pp. 54-60.

[12] Yavini D. T., Taura H. U., Mohammed N. and Namo M. J. (2014). Comparative Study of Mesophilic Biogas Production Potentials of Selected Agro-Wastes. The International Journal of Engineering and Science (IJES) 3 (2), Pp. 1-6.

[13] Dabroska, M., Swietochowski A and Lisowski, A (2019). Physicochemical properties and agglomeration parameters of biogas digestate with addition of calcium carbonate.

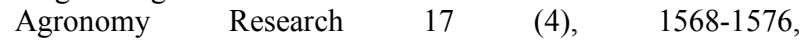
doi.org/10.15159/AR.19.161.

[14] Neczaj E., Bien J., Grosser A., Worwag M., and Kacprzak M. (2012). Anaerobic Treatment of Sewage Sludge and Grease Trap Sludge in Continuous Co-Digestion. Global NESTJ, 14 (2): 141-148.

[15] Aremu, M. O. \& Agarry S. E, (2012) Comparison of Biogas production from cow dung and pig dung under mesophilic condition, International Refereed journal of Engineering and science (IRJES) ISSN (Online) 2319-183X, (Print) 2319-1821 Volume1, Issue4 (December2012), PP, 16-21.

[16] Soliu, G. A \& Onunka, C. (2019). The use of solid fuel for biogas production in a biodigester. International Conference on Engineering for Sustainable World, Journal of Physics; Conference Series 1378 (2019) 022093, doi: 10.1088/17426596/1378/2/022093.

[17] Babatola, J. O. (2008) Comparative study of biogas yield pattern in some animal and household wastes. African Research Review., 2 (4); 54-68, Odeyemi 2011, Energy commission of Nigeria 1998, Kombo 2011, C2007 A. C Wikie, Energy commission of Nigeria1997. 